\title{
Phytoremediation of arsenic using a chemical stabilizer and Eleocharis macrostachya in a contaminated mining soil
}

\author{
J.M. Ochoa-Rivero ${ }^{1}$, M.A. Olmos-Márquez ${ }^{2}$, C.G. Sáenz-Uribe ${ }^{2}$ \& M.T. Alarcón-Herrera ${ }^{3}$ \\ ${ }^{1}$ Instituto Nacional de Investigaciones Forestales, Agrícolas y Pecuarias (INIFAP)-CIRNOC-Experimental Station \\ La Campana, Aldama, Chih., Mexico \\ ${ }^{2}$ Facultad de Zootecnia y Ecología, Universidad Autónoma de Chihuahua, Chihuahua, Chih., Mexico \\ ${ }^{3}$ Centro de Investigación en Materiales Avanzados (CIMAV, S.C.), Chihuahua, Chih., Mexico
}

\begin{abstract}
Arsenic (As) is a highly toxic metalloid that occurs naturally in the environment, however, anthropogenic activities have also caused this element occurrence in water and soil. The objective of this study was to evaluate phytoremediation capacity of Eleocharis macrostachya to remove As from the mining soils using cryptomelane $\left(\mathrm{KMn}_{8} \mathrm{O}_{16}\right)$ as a chemical stabilizer. Experiment was established under greenhouse conditions during 70 days ( 10 weeks) using 20 pots with capacity of $3 \mathrm{~kg}$ of soils. 15 pots were applied $5 \mathrm{~g}$ of cryptomelane, while five pots were considered as a blank. The variables determined were soluble and total As in soil and plant (root and stem). $89 \%$ of the As was retained in the root and the rest in stem. The arsenic concentration, both in root and stem, was higher in the control soil than that with cryptomelane addition, which confirms that the chemical stabilizer retains or maintains less bioavailable arsenical compounds.
\end{abstract}

\section{INTRODUCTION}

Arsenic (As) is a highly toxic metalloid that occurs naturally in the environment, however, anthropogenic activities have also caused this element occurrence in water and soil (Han et al., 2003; Hettiarachchi et al., 2000). Once in the ecosystem, As affects the quality of soils and waters used for various productive activities (Singh et al., 2015). In contrast to conventional treatments (physicochemical), which require long periods of time, involve high costs and can generate residual compounds, phytoremediation that develops the stabilization, transformation and degradation of pollutants, has the characteristics of being an ecological alternative, implemented in situ and have social acceptability (Wani et al., 2017; Singh et al., 2015). The objective of this study was to evaluate phytoremediation capacity of Eleocharis macrostachya to remove As in the mining soils using cryptomelane $\left(\mathrm{KMn}_{8} \mathrm{O}_{16}\right)$ as a chemical stabilizer.

\section{METHODS/EXPERIMENTAL}

\subsection{Soil sampling and experimental}

The soil collected for this study was taken from the surroundings of Avalos smelter $\left(28^{\circ} 37^{\prime} 17.32^{\prime \prime} \mathrm{N}\right.$, $\left.106^{\circ} 00^{\prime} 12.73^{\prime \prime} \mathrm{W}\right)$. Soil samples were taken at $0.30 \mathrm{~m}$ of depth from six points near to the tailing dam. Experiment was under greenhouse conditions during 70 days (10 weeks) an experiment of 20 pots with capacity of
$3 \mathrm{~kg}$ of soils, 15 pots were applied $5 \mathrm{~g}$ of cryptomelane $\left(\mathrm{KMn}_{8} \mathrm{O}_{16}\right)$ chemical stabilizer while 5 pots were used as control. After ten days of the stabilizer addition in the soil, Eleocharis macrostachya, collected of natural wetland in Chihuahua, Mexico, was planted. The variables that were measured are soluble and total As in soil and plant (root and stem).

\subsection{Arsenic analysis}

Arsenic concentrations in soil and plant were analyzed after 70 days of the experiment. The samples were analyzed for total and soluble arsenic by atomic absorption spectrometer (AAS) according NMX-AA132-SCFI-2016, using $\mathrm{HACH}^{\circledR}$ spectrometer model $\mathrm{DR} 2000^{\mathrm{TM}}$.

\section{RESULTS AND DISCUSSION}

\subsection{Total and soluble arsenic in soil}

Table 1 shows the average concentrations of total and soluble As determined in soil at the end of the experiment.

\subsection{Roots and stem}

$89 \%$ of the As stabilized by soil was retained in the root and the rest in stem, both for the samples treated with the stabilizer and for the control targets. When stabilizer was used, the average As concentration in 
Table 1. Total and soluble As concentrations in soil after 70 days.

\begin{tabular}{|c|c|c|c|}
\hline Treatment & $\begin{array}{l}\text { Total As } \\
\left(\mathrm{mg} \mathrm{kg}^{-1}\right)\end{array}$ & $\begin{array}{l}\text { Soluble As } \\
\left(\mu \mathrm{g} \mathrm{L}^{-1}\right)\end{array}$ & $\begin{array}{l}\text { U.S. EPA } \\
\text { Permissible } \\
\text { limit } \\
\left(\mathrm{mg} \mathrm{kg}^{-1}\right)\end{array}$ \\
\hline $\begin{array}{l}\text { Initial As } \\
\text { concentration } \\
\text { in soil }\end{array}$ & $2,796.62$ & 8.07 & $24 \mathrm{mg} \mathrm{kg}^{-1}$ \\
\hline $\begin{array}{l}\text { As concentration } \\
\text { in soil (after } \\
\text { stab.) }\end{array}$ & 2044.47 & $\mathrm{~N} / \mathrm{D}$ & - \\
\hline $\begin{array}{l}\text { As concentration } \\
\text { in soil (after } \\
\text { phyt. + estab.) }\end{array}$ & 2409.97 & 7.97 & - \\
\hline
\end{tabular}

Table 2. Descriptive statistics of concentrations of As in roots (a) and stem (b) of Eleocharis macrostachya.

\begin{tabular}{llllll}
$\begin{array}{l}\text { (a) Roots } \\
\text { Treatment }\end{array}$ & $\mathrm{n}$ & mean & SE & $\min$ & $\max$ \\
\hline $\begin{array}{l}\text { Phytoremediation } \\
\text { (stabilizer) }\end{array}$ & 15 & 779.26 & 135.61 & 361.69 & 1119.55 \\
$\begin{array}{l}\text { Phytoremediation } \\
\text { (without stab.) }\end{array}$ & 5 & 877.72 & 122.45 & 173.18 & 1869.01 \\
\hline
\end{tabular}

*SE: Standard Error

(b) Stem

\begin{tabular}{llllll} 
Treatment & $\mathrm{n}$ & mean & $\mathrm{SE}$ & $\min$ & $\max$ \\
\hline
\end{tabular}

$\begin{array}{llllll}\text { Phytoremediation } & 15 & 105.17 & 15.80 & 25.58 & 252.30\end{array}$ (stabilizer)

$\begin{array}{llllll}\text { Phytoremediation } & 5 & 77.66 & 20.87 & 27.34 & 154.47\end{array}$

(without stab.)

*SE: Standard Error

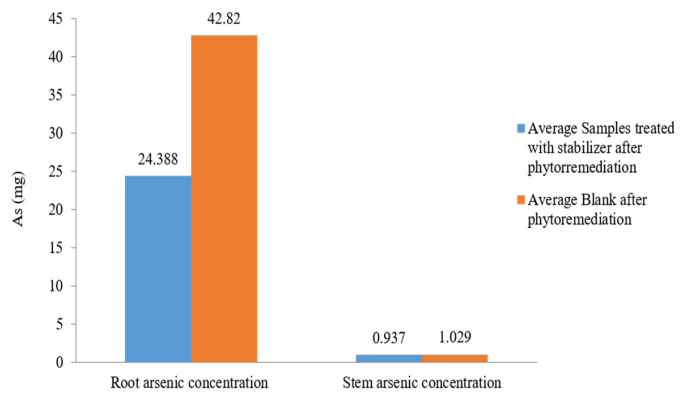

Figure 1. The average As concentrations in roots and stem after stabilizer apply.

the root was $779.26 \mathrm{mg} \mathrm{kg}^{-1}$, while for the stem it was $105.17 \mathrm{mg} \mathrm{kg}^{-1}$ (Fig. 1). In the controls average As concentration in root was higher than plants with stabilizer, with an As concentration of $877.72 \mathrm{mg} \mathrm{kg}^{-1}$.

It is important to mention that reproduction and development of plants in both treatments were

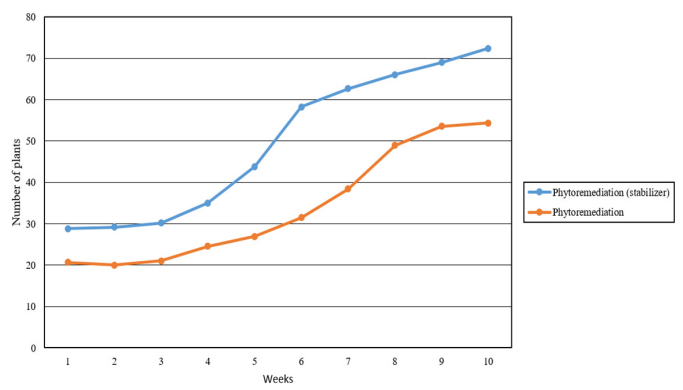

Figure 2. Reproduction of Eleocharis macrostachya in both treatments.

similar (Fig. 2). Tendency was positive during experiment ( 70 days or 10 weeks).

\section{CONCLUSIONS}

The maximum decrease in the soluble arsenic concentration was presented with the application of the chemical stabilizer. The concentration of arsenic after phytoremediation in the control targets and in the soil samples treated with the stabilizer was similar. On the other hand, the arsenic concentration, both in root and stem, were higher in the plants planted in the control soil, which confirms that the chemical stabilizer retains or maintains less bioavailable arsenical compounds.

\section{ACKNOWLEDGEMENTS}

This work was financially supported by National Council for Science and Technology (CONACYT), within the program Attention to National Problems.

\section{REFERENCES}

Han, F.X., Su, Y., Monts, D.L., Plodinec, M.J., Banin, A. \& Triplett, G.E. 2003. Assessment of global industrialage anthropogenic arsenic contamination. Naturwissenschaften, 90(9): 395-401.

Hettiarachchi, G.M., Pierzynski, G.M. \& Ransom, M.D. 2000. In situ stabilization of soil lead using phosphorus and manganese oxide. Environ. Sci. Technol. 34(21): 4614-4619.

Razo, I., Carrizales, L., Castro, J., Díaz-Barriga, F., \& Monroy, M. 2004. Arsenic and heavy metal pollution of soil, water and sediments in a semi-arid climate mining area in Mexico. Water Air Soil Pollut. 152(1-4): 129-152.

Singh, R., Singh, S., Parihar, P., Singh, V.P.Y. \& Prasad, S.M. 2015. Arsenic contamination, consequences and remediation techniques: a review. Ecotoxicol. Environ. Saf. 112: $247-270$.

Wani, R.A., Ganai, B.A.M. \& Shah, A. 2017. Heavy metal uptake potential of aquatic plants through phytoremediation technique - a review. J. Bioremediat. Biodegrad. 8(404): 2. 